\title{
Assessment of the Effective Impact of Bisphenols on Mitochondrial Activity and Steroidogenesis in a Dose-Dependency in Mice TM3 Leydig Cells
}

\author{
T. JAMBOR ${ }^{1}$, E. KOVACIKOVA ${ }^{2}$, H. GREIFOVA ${ }^{1}$, A. KOVACIK ${ }^{1}$, L. LIBOVA ${ }^{3}$, \\ N. LUKAC ${ }^{1}$
}

${ }^{1}$ Department of Animal Physiology, Faculty of Biotechnology and Food Sciences, Slovak University of Agriculture in Nitra, Nitra, Slovak Republic, ${ }^{2}$ AgroBioTech Research Centre, Slovak University of Agriculture in Nitra, Nitra, Slovak Republic, ${ }^{3}$ Faculty of Health and Social Work St. Ladislav, St. Elisabeth University of Health Care and Social Work, Bratislava, Slovak Republic

Received May 3, 2019

Accepted June 24, 2019

Epub Ahead of Print July 25, 2019

\section{Summary}

The increasing worldwide production of bisphenols has been associated to several human diseases, such as chronic respiratory and kidney diseases, diabetes, breast cancer, prostate cancer, behavioral troubles and reproductive disorders in both sexes. The aim of the present in vitro study was to evaluate the potential impact bisphenols $\mathrm{A}, \mathrm{B}, \mathrm{S}$ and $\mathrm{F}$ on the cell viability and testosterone release in TM3 Leydig cell line. Mice Leydig cells were cultured in the presence of different concentrations of bisphenols (0.04-50 $\left.\mu \mathrm{g} \cdot \mathrm{ml}^{-1}\right)$ during $24 \mathrm{~h}$ exposure. Quantification of the cell viability was assessed using the metabolic activity assay, while the level of testosterone in cell culture media was determined by enzyme-linked immunosorbent assay. Within the panel of substances under investigations, the higher experimental concentrations (10; 25 and $50 \mu \mathrm{g} \cdot \mathrm{ml}^{-1}$ ) significantly $(P<0.001)$ decreased Leydig cells viability, while the same doses of BPA and BPB also reduced testosterone production significantly $(P<0.001)$. Taken together, the results of our study reported herein is a consistent whit the conclusion that higher experimental doses of bisphenols have a cytotoxic effect and could have a dose-dependent impact on testosterone production.

\section{Key words}

Bisphenols • Leydig cells • Viability • Testosterone

\section{Corresponding author}

Tomas Jambor, Department of Animal Physiology, Faculty of
Biotechnology and Food Sciences, Slovak University of Agriculture in Nitra, Tr. A. Hlinku 2, 94976 Nitra, Slovak Republic. E-mail: tomasjambor1@gmail.com

Bisphenol A (BPA, 2,2-bis[4-hydroxyphenyl] propane) is one of the oldest and most studied synthetic substance known as an endocrine disruptor (ED). About $70 \%$ of BPA production is used to produce polycarbonate plastics used in a variety of common products such as plastic packaging, cling film, epoxy resins, food cans and many others (Vandenberg et al. 2007). Many studies showed that BPA may definitely affect steroidogenic process through alterations in steroidogenic enzymes and transport proteins, including impairment of spermatogenesis followed by reduced semen quality parameters (Ye et al. 2011, Hulak et al. 2013, Vitku et al. 2015). Due to many negative effects, toxicity and widespread exposure, use of BPA has been banned in some consumer products such as reusable food or beverage containers, infant formula containers and baby bottles (Eladak et al. 2015). Nowadays, there are several analogues to BPA such as bisphenol S (BPS), bisphenol $\mathrm{F}$ (BPF) or bisphenol B (BPB). According to the previous studies, a direct inhibition of bisphenol alternatives on steroidogenesis or spermatogenesis, with irreversible changes in sperm morphology, Sertoli cells activity and hormonal imbalance is extensively discussed 
(Cao et al. 2012, Liao and Kannan, 2013). In addition, many authors confirmed neurotoxicity, genotoxicity, reproductive toxicity and strong endocrine disruptive activity (Alves et al. 2013, Rosenmai et al. 2014). Nowadays, toxicological data are scarce and experimental studies evaluating the effects of bisphenol analogues are unclear. Under these endpoints, we have decided to urgently investigate the effects of BPA, BPB, BPS and $\mathrm{BPF}$ as well as their cellular toxicity and potential impact on steroidogenesis in vitro.

The TM3 Leydig cell line (ATCC \#CRL-1714; Manassas, VA, USA) were cultured in Dulbecco's Modified Eagle's Medium/Nutrient Mixture (Ham's) F12 with HEPEs and $\mathrm{NaHCO}_{3}$ (DMEM/F12; Sigma Aldrich, St. Louis, USA) supplemented with $5 \%$ horse serum (HS; Gibco-Life Technologies, New Zealand), $2.5 \%$ fetal bovine serum (FBS; BiochromAG, Berlin, Germany), $2.5 \mathrm{mM}$ L-glutamine (Sigma Aldrich, St. Louis, USA) and $1 \%$ penicillin/streptomycin solution (Sigma Aldrich, St. Louis, USA). The Leydig cells density was adjusted to a final concentration of $4 \times 10^{3}$ cells/well and seeded in 96-well plate for $24 \mathrm{~h}$. TM3 cells were maintained at $37{ }^{\circ} \mathrm{C}$ under a humidified atmosphere of $95 \%$ air and $5 \% \mathrm{CO}_{2}$. Afterwards, the medium was changed to include different concentrations of bisphenols A, B, S and F (Sigma Aldrich, St. Louis, USA), starting from 0.04 to $50 \mu \mathrm{g} . \mathrm{ml}^{-1}$ and the cells remained cultured during the next $24 \mathrm{~h}$. The applied concentrations range of bisphenols was selected according to the results of our pilot range-finding experiments. The viability of exposed cells was estimated using the MTT (3-4,5-dietyltiazol-2-yl)-2,5diphenyltetratzolium bromide) assay, which measured the reduction of a yellow tetrazolium salt to blue formazan in viable cells (Mosmann 1983). Formed formazan crystals were dissolved by isopropanol (p.a. CentralChem, Bratislava, Slovak Republic) and read by an ELISA reader (Multiscan FC, ThermoFisher Scientific, Vantaa, Finlad) at $570 \mathrm{~nm}$ against $620 \mathrm{~nm}$ wavelengths. Furthermore, the level of testosterone in cell culture media was determined by enzyme-linked immunosorbent assay using ELISA kits purchased from Dialab (Testosterone Cat. \#K00234 Austria). The absorbance was measured at $450 \mathrm{~nm}$ by ELISA reader (Multiscan FC, ThermoFisher Scientific, Vantaa, Finlad). The data were collected from four $(n=4)$ independent experiments that were performed in triplicates and statistically analyzed using the GraphPad prism 5.0 (GraphPad Software Incorporated, San Diego California, USA). One-way analysis of variance (ANOVA) followed by Dunnett's test was used for statistical evaluations. Results were presented as means ( \pm SEM) of Leydig cell viability $\%$ and testosterone $\%$ of control (untreated) and treated groups. Differences were compared for statistical significance at $P<0.05$.
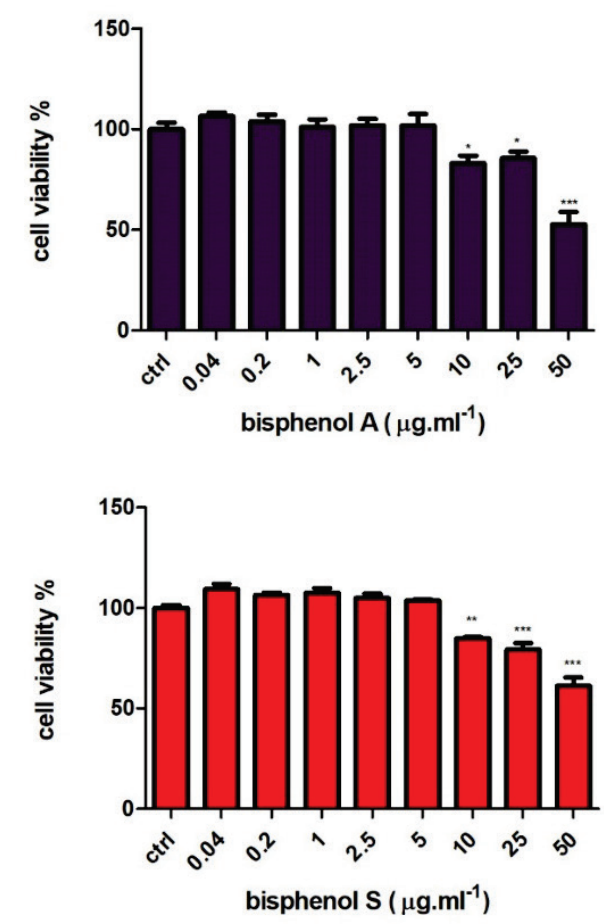
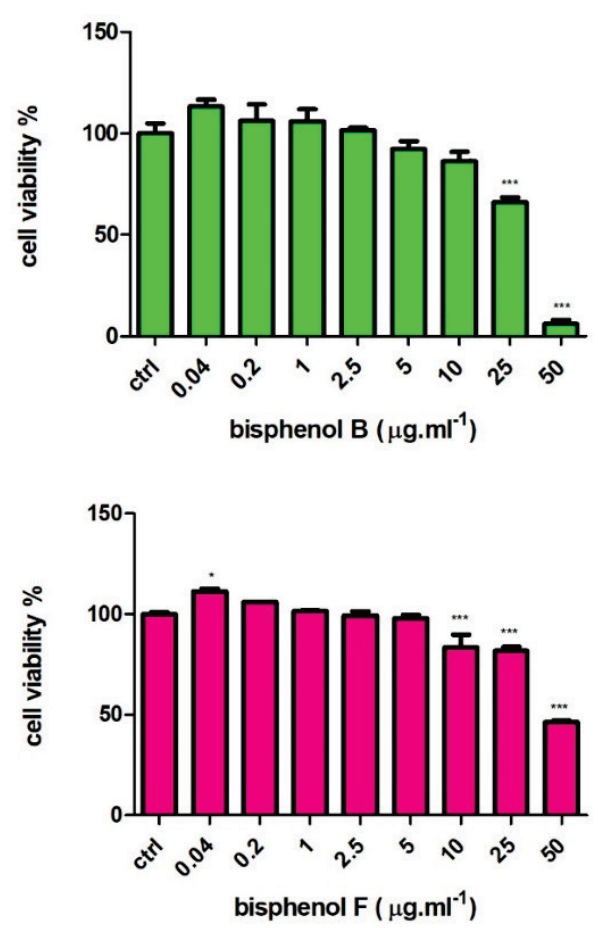

Fig. 1. The effects of bisphenols $A, B, S$ and $F$ on the TM3 cell viability after $24 \mathrm{~h}$ in vitro cultivation. Abbreviations: ctrl - control (non-treated) group. The numbers under each column (0.04-50 $\mu \mathrm{g} \cdot \mathrm{ml}^{-1}$ ) represent experimental concentrations of bisphenols. Each bar represents the mean ( \pm SEM) viability $\%$ of control and treated group. Data were obtained from four $(n=4)$ independent experiments that were performed in triplicates. Level of significance was set at $*(P<0.05), * *(P<0.01)$ and $* * *(P<0.001)$. Statistical difference between the values of control and treated groups is indicated by an asterisk. 


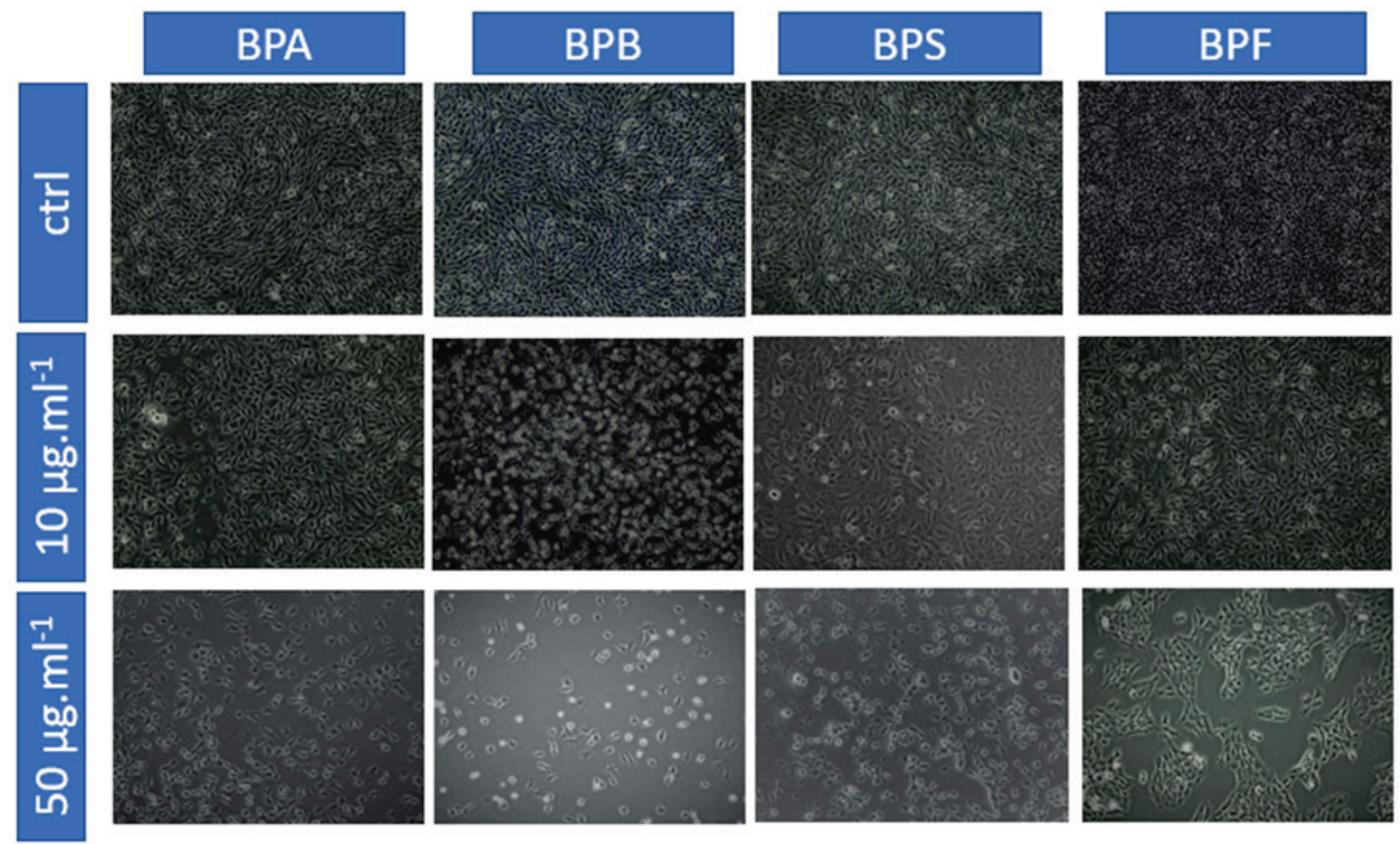

Fig. 2. A photomicrograph of TM3 cells after $24 \mathrm{~h}$ treatment with bisphenols $A, B, S$ and $F$ at $400 x$ magnification. Abbreviations: ctrl control (non-treated) group. The numbers 10 and $50 \mu \mathrm{g} \cdot \mathrm{ml}^{-1}$ represent experimental concentrations of bisphenols. BPA - bisphenol A, $\mathrm{BPB}$ - bisphenol B, BPS - bisphenol S, BPF - bisphenol F.

Table 1. Measurements of testosterone production after exposure to bisphenols during $24 \mathrm{~h}$ incubation in TM3 Leydig cells. $* * * P<0.001, * * P<0.05, \mathrm{ctrl}-$ control group

\begin{tabular}{|c|c|c|c|c|}
\hline \multirow{2}{*}{$\begin{array}{l}\text { Experimental doses of } \\
\text { bisphenols }\left(\mu \mathrm{g} \cdot \mathrm{ml}^{-1}\right)\end{array}$} & \multicolumn{4}{|c|}{ Test compound } \\
\hline & BPA & BPB & BPS & BPF \\
\hline$c t r l$ & $100.0 \pm 5.1 \%$ & $100.0 \pm 4.8 \%$ & $100.0 \pm 3.0 \%$ & $100.0 \pm 4.6 \%$ \\
\hline 0.04 & $113.7 \pm 7.3 \%$ & $110.3 \pm 1.6 \%$ & $108.6 \pm 5.8 \%$ & $120.2 \pm 2.0 \%$ \\
\hline 0.2 & $115.5 \pm 9.1 \%$ & $109.0 \pm 2.8 \%$ & $107.1 \pm 5.5 \%$ & $115.7 \pm 5.0 \%$ \\
\hline 1 & $119.4 \pm 2.4 \%$ & $111.3 \pm 5.0 \%$ & $105.0 \pm 3.8 \%$ & $115.9 \pm 4.6 \%$ \\
\hline 2.5 & $120.0 \pm 4.6 \%$ & $106.7 \pm 3.5 \%$ & $107.5 \pm 9.1 \%$ & $102.0 \pm 8.5 \%$ \\
\hline 5 & $116.0 \pm 3.7 \%$ & $108.7 \pm 3.2 \%$ & $115.1 \pm 1.4 \%$ & $109.7 \pm 6.4 \%$ \\
\hline 10 & $69.6 \pm 8.3 \%{ }^{* *}$ & $59.0 \pm 1.9 \%^{* * *}$ & $91.2 \pm 2.0 \%$ & $99.9 \pm 7.6 \%$ \\
\hline 25 & $30.8 \pm 2.9 \%{ }^{* * *}$ & $23.9 \pm 4.1 \%{ }^{* * *}$ & $93.1 \pm 1.1 \%$ & $96.2 \pm 7.1 \%$ \\
\hline 50 & $20.5 \pm 3.5 \%{ }^{* * *}$ & $9.0 \pm 2.4 \%{ }^{* * *}$ & $80.6 \pm 8.2 \%$ & $86.2 \pm 2.1 \%$ \\
\hline
\end{tabular}

Abbreviations: ctrl - control group; BPA - bisphenol A, BPB - bisphenol B, BPS - bisphenol F, BPF - bisphenol F. Each number represent the mean $( \pm$ SEM) testosterone $\%$ of control (untreated) and treated groups. Data were obtained from four $(n=4)$ independent experiments that were performed in triplicates. Level of significance was set at $* *(P<0.01)$ and $* * *(P<0.001)$. Statistical difference between the values of control and treated groups is indicated by an asterisk.

As presented in Figure 1. the metabolic activity was significantly $(P<0.05 ; \quad P<0.001)$ reduced at $10 \quad(83.06 \pm 3.82 \%) ; \quad 25 \quad(85.63 \pm 3.36 \quad \%) \quad$ and $50 \quad(52.79 \pm 6.05 \%) \quad \mu \mathrm{g} . \mathrm{ml}^{-1}$ of BPA. Significant
$(P<0.001)$ changes were also observed at the $25(66.08 \pm 2.34 \%)$ and $50(6.13 \pm 1.87 \%) \mu \mathrm{g} \cdot \mathrm{ml}^{-1}$ of BPB, while $10 \quad(84.81 \pm 0.70 \%$ and $83.46 \pm 6.22 \%)$; $25(79.47 \pm 2.97 \% ; 81.82 \pm 2.00 \%)$ and $50(61.30 \pm 4.14 \%$ 
and $46.31 \pm 0.77 \%) \mu \mathrm{g} . \mathrm{ml}^{-1}$ of BPS and BPF decreased Leydig cell viability significantly $(P<0.01 ; P<0.001)$. The data suggest that the highest dose of BPB $\left(50 \mu \mathrm{g} \cdot \mathrm{ml}^{-1}\right)$ is extremely cytotoxic and the suppression may be increased by other bisphenols with time. The cytotoxic effects of bisphenols are shown at the photomicrograph (Fig. 2). BPA is one of the most well-studied endocrine disruptors (Kolatorova et al. 2017). The ability to affect the cell viability of Leydig TM3 line in dose- and time- dependent manner of BPA in vitro was evaluated by Goncalves et al. (2018). The data showed that at concentrations above $5 \mu \mathrm{M}(10-500 \mu \mathrm{M})$ during $24 \mathrm{~h}$ exposure to BPA significantly inhibited mitochondrial activity when compared to the control group. Nonetheless, the Leydig cell viability did not decrease significantly after $48 \mathrm{~h}$ exposure to BPA at concentrations below $50 \mu \mathrm{M}$. In this case, higher experimental doses (100-500 $\mu \mathrm{M})$ of BPA reduced mitochondrial activity significantly. Roelofs et al. (2015) determined the metabolic activity of MA-10 cells after $48 \mathrm{~h}$ BPS and BPF exposure. The results showed non-cytotoxic effect at 0.01-30 $\mu \mathrm{M}$ of BPS and 0.01-100 $\mu \mathrm{M}$ of BPF. The cytotoxic potential of BPS, BPB and BPF (10-300 $\mu \mathrm{M})$ after $48 \mathrm{~h}$ incubation was investigated in the in vitro study by Russo et al. (2018). The biological effect was evaluated using a wellestablished health and cancer cell lines (HeLa, MCF-7 and 3T3-L1). Moderate toxicity was observed for BPF and BPS on all cell lines, while BPB was clearly toxic only for 3T3-L1 (mouse embryonic fibroblast) and MCF-7 (human breast cancer) cells.

The results of our in vitro study indicate that experimental concentrations of BPA, BPB, BPS and BPF (0.04-50 $\mu \mathrm{g} \cdot \mathrm{ml}^{-1}$ ) may affect the testosterone production in mice TM3 Leydig cells after $24 \mathrm{~h}$ exposure. A significant $(P<0.01 ; P<0.001)$ reduction in hormone production was recorded at $10 \quad(69.66 \pm 8.32 \%$ and $59.93 \pm 1.96 \%) ; 25(30.88 \pm 2.91 \% ; 22.94 \pm 4.41 \%)$ and $50(20.54 \pm 3.51 \% ; 9.60 \pm 2.46 \%) \mu \mathrm{g} . \mathrm{ml}^{-1}$ of BPA and BPB compared to the controls. On the other hand, BPS and BPF slightly reduced testosterone synthesis at the same concentrations, but not significantly. We are convinced that the highest experimental dose of BPA and BPB have a strong inhibitory potential evoked by decreasing in steroidogenic enzymes activity such as
$3 \beta$-HSD or $17 \beta$-HSD. A summary of testosterone production after $24 \mathrm{~h}$ treatment by bisphenols $\mathrm{A}, \mathrm{B}, \mathrm{S}$ and F in TM3 Leydig cells is presented in Table 1. Similar tendency was observed in the previous study of Ok et al. (2017). They showed significant inhibition of testosterone and progesterone production by $100 \mu \mathrm{M}$ of BPA treatment in comparison to the control group after $24 \mathrm{~h}$ exposition in TM3 cell line in vitro. Goncalves et al. (2018) study showed that the concentrations 1, 10 and $100 \mu \mathrm{M}$ of BPA are able to reduce testosterone production in TM3 Leydig cell line after $48 \mathrm{~h}$ incubation by approximately 22-39\% respectively, when compared to the non-treated cells. Testosterone production in MA-10 cells after $48 \mathrm{~h}$ in vitro exposure to experimental doses (0.01-100 $\mu \mathrm{M})$ of BPF and BPS was evaluated by Roelofs et al. (2015). Exposure to both of selected bisphenols in concentrations ranges of 0.01-30 $\mu \mathrm{M}$ for BPS, and up to $100 \mu \mathrm{M}$ for BPF showed that only BPF increased testosterone production, while BPS did not affect this production in exposed cells. Suppression of testosterone synthesis may be associated with inhibition of steroidogenic enzyme activity because there was a decrease in steady state mRNA levels of the cytochrome P450 17 $\alpha$-hydroxylase/17,20 lyase, StAR and Hsb3b1, although statistical significance was not reached (Akingbemi et al. 2004, Eladak et al. 2015)

In conclusion, our results showed that higher experimental concentrations from 10 to $50 \mu \mathrm{g} \cdot \mathrm{ml}^{-1}$ of BPA, BPS and BPF as well as 25 or $50 \mu \mathrm{g} \cdot \mathrm{ml}^{-1}$ of BPB, may adversely affect the viability of TM3 Leydig cells after $24 \mathrm{~h}$ in vitro cultivation. The results also suggest that all experimental doses (0.04-50 $\left.\mu \mathrm{g} . \mathrm{ml}^{-1}\right)$ of bisphenols may affect testosterone release while the highest concentrations have inhibitive effects on steroid hormone production.

\section{Conflict of Interest}

There is no conflict of interest.

\section{Acknowledgements}

This work was financially supported by the Slovak Research and Development Agency Grant no. APVV-160289, APVV-15-0543. This work was also supported by the Ministry of Education, Science, Research and Sport of the Slovak Republic project no. VEGA 1/0539/18. 


\section{References}

AKINGBEMI BT, SOTTAS CM, KOULOVA AI, KLINNEFELTER GR, HARDA MP: Inhibition of testicular steroidogenesis by the xenoestrogen bisphenol A is associated with reduced pituitary luteinizing hormone secretion and decreased steroidogenic enzyme gene expression in rat Leydig cells. Endocrinology 145: 592-603, 2004.

ALVES MG, RATO L, CARVALHO RA, MOREIRA PI, SOCORRO S, OLIVIERA PF: Hormonal control of Sertoli cell metabolism regulates spermatogenesis. Cell Mol Life Sci 70: 777-793, 2013.

CAO XL, ZHANG J, GOODYER CG, HAYWARD S, COOKE GM, CURRAN IH: Bisphenol A in human placental and fetal liver tissues collected from Greater Montreal area (Quebec) during 1998-2008. Chemosphere 89: 505-511, 2012.

ELADAK S, GRISIN T, MOISON D, GUERQUIN MJ, N'TUMBA-BYN T, POZZI-GAUDIN S, BENACHI A, LIVERA G, ROUILLER-FABRE V, HABERT R: A new chapter in the bisphenol A story: bisphenol S and bisphenol $\mathrm{F}$ are not safe alternatives to this compound. Fertil and Steril 103: 11-21, 2015.

GONCALVES GD, SAMPREBON SC, BIAZI BI, MANTOVANI MS, FERNANDES GS: Bisphenol A reduces testosterone production in TM3 Leydig cells independently of its effects on cell death and mitochondrial membrane potential. Reprod Toxicol 76: 26-34, 2018.

HULAK M, GAZO I, SHALIUTINA A, LINHARTOVA P: In vitro effects of bisphenol A on the quality parameters, oxidative stress, DNA integrity and adenosine triphosphate content in sterlet (Acipenser ruthenus) spermatozoa. Comp Biochem Physiol C Toxicol Pharmacol 158: 64-71, 2013.

KOLATOROVA L, DUSKOVA M, VITKU J, STARKA L: Prenatal exposure to bisphenols and parabens and impacts on human physiology. Physiol Res 66 (Suppl 3): S305-S315, 2017.

LIAO C, KANNAN K: Concentrations and profiles of bisphenol A and other bisphenol analogues in foodstuffs from the United States and their implications for human exposure. J Agric Food Chem 61: 4655-4662, 2013.

MOSMANN T: Rapid colorimetric assay for cellular growth and survival: application to proliferation and cytotoxicity assays. J Immunol Methods 65: 55-63, 1983.

OK S, KANG JS, KIM KM: Cultivated wild ginseng extracts upregulate the anti-apoptosis systems in cells and mice induced by bisphenol A. Mol Cell Toxicol 13: 73-82, 2017.

ROELOFS MJ, VAN DEN BERG M, BOVEE TF, PIERSMA AH, VAN DUURSEN MB: Structural bisphenol analogues differentially target steroidogenesis in murine MA-10 Leydig cells as well as the glucocorticoid receptor. Toxicology 329: 10-20, 2015.

ROSENMAI, AK, DYDBAHL M, PEDERSEN M, VAN VUGT-LUSSENBURG BM, WEDEBYE EB, TAXVIG C, VINGGAARD AM: Are structural analogues to bisphenol a safe alternatives? Toxicol Sci 139: 35-47, 2014.

RUSSO G, CAPUOZZO A, BARBATO F, IRACE C, SANTAMARIA R, GRUMETTO L: Cytotoxicity of seven bisphenol analogues compared to bisphenol A and relationships with membrane affinity data. Chemosphere 201: 432-440, 2018.

VANDENBERG LN, HAUSER R, MARCUS M, OLEA N, WELSHONS WV: Human exposure to bisphenol A (BPA). Reprod Toxicol 24: 139-177, 2007.

VITKU J, SOSVOROVA L, CHLUPACOVA T, HAMPL R, HILL M, SOBOTKA V, HERACEK J, BICIKOVA M, STARKA L: Differences in bisphenol A and estrogen levels in the plasma and seminal plasma of men with different degrees of infertility. Physiol Res 64 (Suppl 2): S303-S311, 2015.

YE L, ZHAO B, HU G, CHU Y, GE RS: Inhibition of human and rat testicular steroidogenic enzyme activities by bisphenol A. Toxicol Lett 207: 137-142, 2011. 